Eur. J. Clin. Chem. Clin. Biochem.

Vol. 31, 1993, pp. 111-114

(C) 1993 Walter de Gruyter \& Co.

Berlin - New York

\title{
Stimulated Cellular Immune System in Patients with Congestive Heart Failure ${ }^{1}$ )
}

\author{
By D. Fuchs ${ }^{1}$, M. Samsonov ${ }^{2}$, G. P. Tilz ${ }^{3}$, G. Reibnegger ${ }^{1}$, J. N. Belenkov ${ }^{2}$, E. L. Nassonov ${ }^{2}$ and H. Wachter ${ }^{1}$ \\ 1 Institut für Medizinische Chemie und Biochemie, Universität Innsbruck, Austria \\ 2 Institute for Clinical Cardiology, Cardiology Research Center, Moscow, Russia \\ 3 Universitätsklinik für Interne Medizin. Graz, Austria
}

(Received October 16, 1992)

Summary: In this cross-sectional study, we analysed serum concentrations of soluble markers of cellular immune activation, namely, interferon- $\gamma$, neopterin (a product of activated macrophages), soluble interleukin- 2 receptor, and soluble $\mathrm{CD} 8$, in 25 patients with congestive heart failure. Ten $(40 \%)$ patients showed increased concentrations (i. e. above the reference ranges of healthy controls) of neopterin, $14(56 \%)$ showed increased soluble interleukin-2 receptor, and $6(24 \%)$ showed increased soluble CD8. Endogenous interferon- $\gamma$ was detectable in 10 patients $(40 \%)$. In addition, we found significant correlations between neopterin and interferon- $\gamma$ ( $\mathrm{rs}=0.417, \mathrm{p}<0.05$ ), and between neopterin and soluble CD8 concentrations ( $\mathrm{rs}=0.430, \mathrm{p}<0.05$ ). All patients with increased soluble CD8 also had increased soluble interleukin-2 receptor. However, no significant correlations of soluble interleukin-2 receptor with soluble CD8 or any of the other quantities were observed.

Increased concentrations of soluble interleukin-2 receptors, soluble CD8 and neopterin indicate that cellular immunity is stimulated in patients with congestive heart failure. Activated CD8-positive T-lymphocytes may represent the source of increased soluble CD8. Endogenous interferon- $\gamma$, which is derived from activated Tcells, may induce neopterin release by monocytes/macrophages.

\section{Introduction}

Patients with congestive heart failure often present with immunological abnormalities $(1-3)$. Viral infections or autoimmune phenomena appear to be involved in the pathogenesis of the disorder $(4,5)$. Serologic evidence of persistent enterovirus infection and enterovirus-specific RNA sequences can be found in myocardial biopsies of patients with myocarditis and dilated cardiomyopathy $(6,7)$.

Recently we described increased concentrations of serum neopterin in patients with chronic myocarditis and dilated cardiomyopathy $(8,9)$. Large amounts of neopterin, which is a pyrazino-pyrimidine-derivative

') Supported by a grant from the "Österreichisches Bundesministerium für Wissenschaft und Forschung", Sektion Forschung. derived biosynthetically from guanosine triphosphate, are released from human macrophages on stimulation with interferon- $\gamma(10)$. Increased neopterin concentrations were observed earlier in patients suffering from diseases which involve activation of the cellular immune system, such as viral infections, allograft rejection, and autoimmune diseases $(10,11)$. Also, in these clinical conditions, increased neopterin may indicate the increased endogenous formation of interferon- $\gamma$, because significant correlations between the concentrations of those two compounds are frequently found $(12,13)$.

In this study, we tried to gain further evidence for cellular immune activation in patients with congestive heart failure. We examined serum concentrations of interferon- $\gamma$, neopterin, and additional immune activation markers, such as soluble interleukin-2 receptor and soluble $\mathrm{CD} 8$ in the serum of patients. 


\section{Patients and Methods}

Ten male patients (mean age $42 \pm 11$ years) with dilated cardiomyopathy according to World Health Organization criteria (14), and 15 patients with chronic myocarditis (14 males, one female, mean age $35 \pm 13$ years), referred to the Cardiology Research Centre were studied. Eighteen patients underwent coronary angiography, none had significant coronary artery disease; endomyocardial biopsy was performed in 15 of the 18 patients. In one patient diagnosis was confirmed at necropsy. Eleven patients had histological evidence of chronic myocarditis. Clinically significant thromboembolic events were documented in eight patients.

Serum concentrations of neopterin were determined with a commercially available readioimmunoassay (IMMUtest, Henning. Berlin, Germany), using standard protocols provided by the manufacturer. Interferon- $\gamma$ was quantified by radioimmunoassay (Centocor, Malvern, PA), employing an optimized application that allows detection of interferon- $\gamma$ with enhanced sensitivity $(13,15)$. This procedure includes two overnight incubation steps, and increases the sensitivity of the assay to a detection limit of $18 \mathrm{U} / \mathrm{l}$. Radioactivity was counted with a gamma counter (CliniGamma 1272; Wallac Oy, Turku, Finland). Cell-free test enzyme immunoassays were used for measurements of soluble interleukin-2 receptor and soluble CD8 (T Cell Sciences. Inc., Cambridge, MA) and quantification was performed using an ELISA-reader (Anthos, Labtec Instruments, Salzburg, Austria).

The concentrations of the analytes were compared with preestablished reference ranges of healthy controls which were provided by the manufacturers of the assays and proven by determinations on healthy volunteers in our laboratories (tab. 1).

Statistical evaluation was done by $\chi^{2}$-test and Fisher's exact test for group comparisons, and Spearman's rank correlation coefficients $\left(r_{s}\right)$ were computed to assess mutual associations between the biochemical results.

\section{Results}

Average serum concentrations of interferon- $\gamma$, neopterin, soluble interleukin-2 receptor and soluble CD8 are listed in table 1 . Serum neopterin, soluble interleukin-2 receptor and soluble CD8 were significantly higher in patients than in healthy controls. Serum
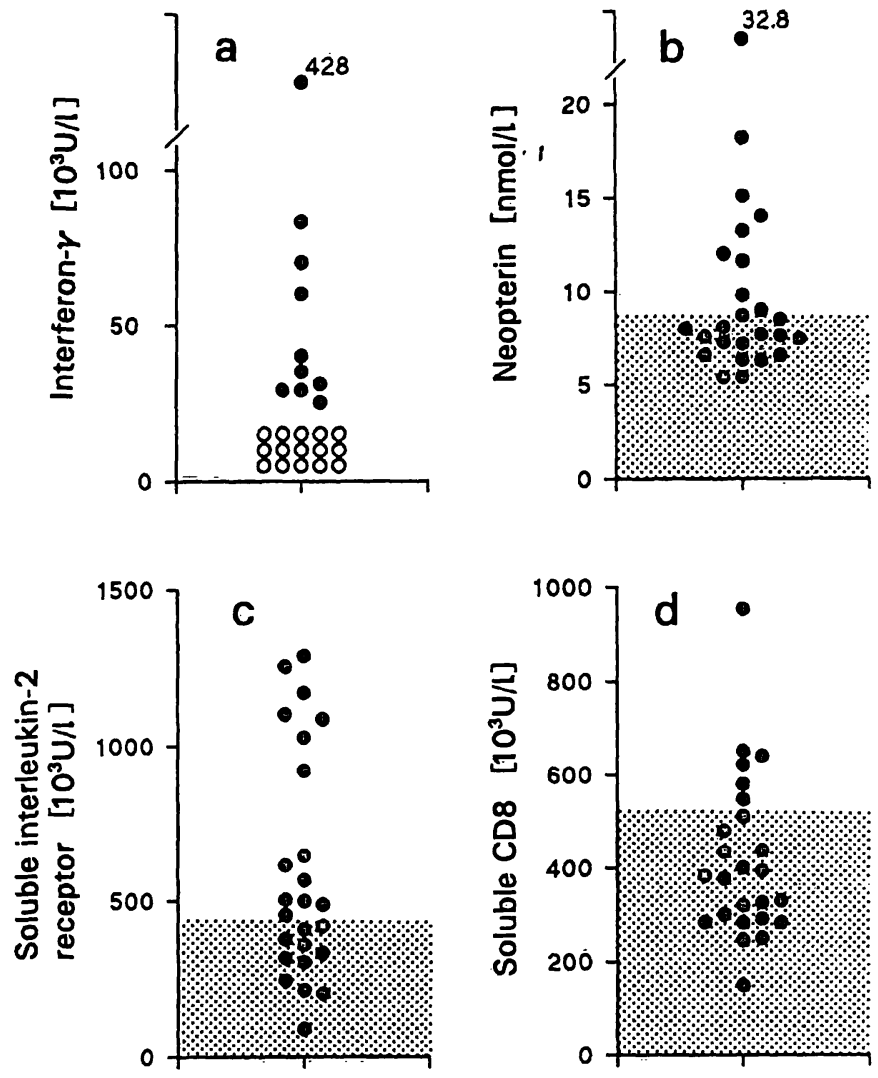

Fig. 1. Serum concentrations of interferon- $\gamma$ (a), neopterin (b), soluble interleukin-2 receptor (c) and soluble CD8 (d) in patients with congestive heart failure. Open circles indicate interferon- $\gamma$ values below the detection limits. The reference range of serum interferon- $\gamma$ extends from undetectable to $100 \mathrm{U} / \mathrm{l}(13)$. The reference ranges of neopterin, soluble interleukin-2 receptor and soluble CD8 in healthy controls (95th percentiles), obtained from earlier studies, are represented by the dotted areas $(11,16)$.

neopterin concentrations was above the upper limit of normal range (95th percentile of healthy controls) in ten patients $(40 \%)$. Six patients $(24 \%)$ had increased soluble CD8, and $14(56 \%)$ had increased soluble interleukin-2 receptor concentrations (fig. 1).

Tab. 1. Serum concentrations of interferon- $\gamma$, neopterin, soluble interleukin-2 receptor and soluble CD8 in 25 patients with congestive heart failure (n. d.: below $18 \mathrm{U} / \mathrm{l}$ )

\begin{tabular}{lllll}
\hline & $\begin{array}{l}\text { Interferon- } \gamma \\
(\mathrm{U} / \mathrm{l})\end{array}$ & $\begin{array}{l}\text { Neopterin } \\
(\mathrm{nmol} / \mathrm{l})\end{array}$ & $\begin{array}{l}\text { Soluble interleukin-2 } \\
\text { receptor } \\
\left(10^{3} \mathrm{U} / \mathrm{l}\right)\end{array}$ & $\begin{array}{l}\text { Soluble CD8 } \\
\left(10^{3} \mathrm{U} / \mathrm{l}\right)\end{array}$ \\
\hline $\begin{array}{l}\text { Mean } \pm \mathrm{SE} \\
\text { Range }\end{array}$ & $33 \pm 17$ & $10.0 \pm 1.2$ & $607 \pm 75$ & $418 \pm 35$ \\
$\begin{array}{l}\text { Patients with } \\
\begin{array}{l}\text { elevated marker } \\
\text { concentrations }\end{array}\end{array}$ & $\mathrm{n} . \mathrm{d} .-428$ & $5.4-32.8$ & $91-1289$ & $150-954$ \\
$\begin{array}{l}\text { Reference range (95th } \\
\text { percentiles) of healthy } \\
\text { controls (11,13, 10) }\end{array}$ & 1 & $10^{*}$ & $14^{*}$ & $6^{* *}$ \\
\hline
\end{tabular}

* significantly increased incidence of elevated concentrations compared with healthy controls $\left(p<0.001, \chi^{2}\right.$-test)

** significantly different from healthy controls $\left(p<0.01, \chi^{2}\right.$-test) 
Tab. 2. Correlations between serum concentrations of interferon- $\gamma$, neopterin, soluble interleukin-2 receptor and soluble CD8 (Spearman's rank correlation coefficients and $\mathrm{p}$-values are shown)

\begin{tabular}{|c|c|c|c|}
\hline & Neopterin & $\begin{array}{l}\text { Soluble } \\
\text { CD8 }\end{array}$ & $\begin{array}{l}\text { Soluble } \\
\text { interleukin-2 } \\
\text { receptor }\end{array}$ \\
\hline Interferon- $\gamma$ & $\begin{array}{l}0.421 \\
\mathrm{p}<0.05\end{array}$ & $\begin{array}{l}0.334 \\
p=0.10\end{array}$ & $\begin{array}{l}-0.264 \\
p=0.21\end{array}$ \\
\hline Neopterin & & $\begin{array}{l}0.439 \\
\mathrm{p}<0.05\end{array}$ & $\begin{array}{l}-0.136 \\
p=0.51\end{array}$ \\
\hline Soluble CD8 & & & $\begin{array}{l}0.303 \\
\mathrm{p}=0.15\end{array}$ \\
\hline
\end{tabular}

Endogenous interferon- $\gamma$ was detectable in ten of 25 patients $(40 \%)$. In one patient the serum concentrations of interferon- $\gamma$ was $428 \mathrm{U} / \mathrm{l}$; this is well above the upper limit of healthy controls which is $100 \mathrm{U} / 1$.

Significant correlations were found between interferon- $\gamma$ and neopterin concentrations, and between neopterin and soluble CD8 concentrations. No correlations existed between the other variables measured (tab. 2).

Seven of the ten patients with increased neopterin also had increased interferon- $\gamma$ concentrations, as had 3 of the 15 patients with normal neopterin $(p=0.02$, Fischer's exact test). All six patients with increased soluble $\mathrm{CD} 8$ had increased soluble interleukin-2 receptor, seven of ten patients with normal soluble CD8 also had increased soluble interleukin-2 receptor $(p=0.01)$. Five of six patients with increased soluble CD8 had increased neopterin, but also six of 19 patients with normal soluble CD8 had abnormal neopterin $(p=$ not significant). There was no apparent association between increased or decreased soluble interleukin-2 receptor, and increased or decreased neopterin and interferon- $\gamma$.

\section{Discussion}

This study shows that a significant percentage of a panel of immune activation markers is elevated in patients with congestive heart failure. Serum concentrations of neopterin, soluble interleukin-2 receptor and soluble CD8 were found to be increased in a variable but significant proportion of patients.

In vitro and in vivo data demonstrated a strong association between increased neopterin formation and the activation of cell mediated immunity $(10,11)$. High neopterin concentrations are known to be closely associated with endogenous formation of cytokines during immune stimulation. Interferon- $\gamma$ is the most potent inducer of neopterin formation and release by human monocytes/macrophages $(11,17)$.

Endogenous interferon- $\gamma$ was detected in less than half of the patients of this study. Although an optimized protocol was used, the sensitivity of the interferon- $\gamma$ assay for the detection of immune activation was much lower than that of the other quantities measured in this study. Interferon- $\gamma$ was outside the normal range in only one patient, who also had the highest neopterin concentration. Nevertheless, a significant association between increased interferon- $\gamma$ and increased neopterin concentrations was found (tab. 2). It is possible that interferon- $\gamma$ is released at local sites of inflammation and does not freely enter the blood stream. Similar observations were made earlier in patients with solid allograft rejections (18). Interferon- $\gamma$ may be released by activated $\mathrm{T}$-cells and induce neopterin formation by monocytes/macrophages. Increased concentrations of soluble interleukin-2 receptor and soluble CD8 found in some patients further support this conclusion. In vitro data show soluble interleukin- 2 receptor and soluble CD8 to be shed from activated and proliferating T-lymphocytes $(19,20)$. In the shedding of soluble interleukin-2 receptor, it is not possible to distinguish between the subpopulations of T-cells involved, but increased soluble CD8 concentrations point to a role of soluble CD8-positive cytotoxic/suppressor cells. Thus, our results favour the view that activated cytotoxic T-lymphocytes play a role in the release of interferon- $\gamma$ in patients with congestive heart failure. In agreement with this assumption a correlation was found between soluble CD8 and neopterin concentrations in the patients. Similar associations between the two quantities have also been described in patients with human immunodeficiency virus (HIV) infection (21).

There were no strong correlations between soluble interleukin-2 receptor and the other variables. Notably, in earlier investigations on patients with HIV infection, the association between neopterin and soluble interleukin-2 receptor concentrations was also found to be rather weak $(16,22)$. The size of the study is, however, too small for a final conclusion.

In earlier studies we found a significant association between increased neopterin concentrations and the stage of patients with congestive heart failure.(8). In addition, several significant correlations were found between functional tests of left ventricles (such as enddiastolic volume and ejection fraction) and neopterin concentrations $(8,9)$. The same abnormalities of left ventricular quantities are significantly associated with outcome in patients with dilated cardiomyopathy (23). Thus, the correlations between neopterin con- 
centrations and other markers of immune stimulation found in this study further support a potential association between immune activation and the pathogenesis of congestive heart failure.

Our study shows that activation of the cellular immune system takes place in patients with congestive

\section{References}

1. Aretz. H. T., Billingham, M. E., Edwards, W. D., Factor, S. M., Fallon, J. T., Fenoglio, J. J., Olsen, E. G. J. \& Schaen, F. J. (1986) Myocarditis: a histopathologic definition and classification. Am. J. Cardiovasc. Pathol. 1, 3-13.

2. See, D. M. \& Tilles, J. G. (1991) Viral myocarditis. Rev. Infect. Dis. 13, 951-956.

3. Maisch, B., Herzum, M., Izumi, T. \& Nunoda, S. (1988) The importance of humoral and cellular immunological parameters for the pathogenesis of viral myocarditis. In: New Concepts in Viral Heart Disease (Schultheiss, H.-P., ed.) pp. 259-275, Springer, Berlin, Germany.

4. Woodruff, J. F. \& Woodruff, J. J. (1984) Involvement of T lymphocytes in the pathogenesis of Coxsackie B3 heart disease. J. Immunol. 113, 1716-1734.

5. Anonymous (1990) Dilated cardiomyopathy and enteroviruses. Lancet 336, 971-973.

6. Muir, P., Nicholson, F., Tilzey, A. J., Signy, M., English, T. A. H. \& Banatvala, J. E. (1989) Chronic relapsing pericarditis and dilated cardiomyopathy: serological evidence of persistent enterovirus infection. Lancet $i, 804-807$.

7. Bowles, N. E., Richardson, P. J., Olson, E. J. G. \& Archard, L. C. (1986) Detection of Coxsackie-B-virus-specific RNA sequences in myocardial biopsy samples from patients with myocarditis and dilated cardiomyopathy. Lancet $i, 1120-$ 1123.

8. Samsonov, M., Fuchs, D., Reibnegger, G., Belenkov, J. N., Nassonov, E. L. \& Wachter, H. (1992) Patterns of serological markers for cellular immune activation in patients with dilated cardiomyopathy and chronic myocarditis. Clin. Chem. 38, 678-680.

9. Rudzite, V., Skards, J. I., Fuchs, D., Reibnegger, G. \& Wachter, H. (1992) Serum kynurenine and neopterin concentrations in patients with cardiomyopathy. Immunol. Letters 32, 125-130.

10. Fuchs, D., Hausen, A., Reibnegger, G., Werner, E. R., Dierich, M. P. \& Wachter, H. (1988) Neopterin as a marker of cell-mediated immunity: Application in HIV infection. Immunol. Today 9, 150-155.

11. Wachter, H., Fuchs, D., Hausen, A., Reibnegger, G. \& Werner, E. R. (1989) Neopterin as marker for activation of cellular immunity: immunological basis and clinical application. Adv. Clin. Chem. 27, 81-141.

12. Fuchs, D., Malkovsky, M., Reibnegger, G., Werner, E. R., Forni, G. \& Wachter, H. (1989) Endogenous release of interferon-gamma and diminished response of peripheral blood mononuclear cells to antigenic stimulation. Immunol. Letters 23, 103-108. heart failure. Virus infection and/or autoimmune disease or both are involved in the aetiology of myocardial inflammation in patients with dilated cardiomyopathy or chronic myocarditis, and immune activation may contribute to the spectrum of symptoms in patients and to progression of the disease.

13. Fuchs, D., Hausen, A., Reibnegger, G., Werner, E. R., Werner-Felmayer, G., Dierich, M. P. \& Wachter, H. (1989) Interferon-gamma concentrations are increased in sera from individuals infected with human immunodeficiency virus type 1. J. Acquir. Immune Def. Syndr. 2, 158-162.

14. Report of the WHO/ISFS task force (1980) Brit. Heart. J. $44,672-673$.

15. Woloszczuk, W. (1985) A sensitive immunoradiometric assay for gamma interferon, suitable for its measurement in serum. Clin. Chem. 31, 1090.

16. Fuchs, D., Jaeger, H., Popescu, M., Reibnegger, G., Werner, E. R., Dierich, M. P., Kaboth, W., Tilz, G. P. \& Wachter, H. (1990) Immune activation markers to predict AIDS and survival in HIV-1 seropositives. Immunol. Letters 26, $75-80$.

17. Werner, E. R., Werner-Felmayer, G., Fuchs, D., Hausen, A., Reibnegger, G., Yim, J. J., Pfleiderer, W. \& Wachter, H. (1990) Tetrahydrobiopterin biosynthetic activities in human macrophages, fibroblasts, THP-1 and T 24 cells. GTPcyclohydrolase I is stimulated by interferon-gamma, 6-pyruvoyl tetrahydropterin synthase and sepiapterin reductase are constitutively present. J. Biol. Chem. 265, 3189-3192.

18. Woloszczuk, W., Troppmair, J., Leiter, E., Flener, R., Schwarz, M., Kovarik, J., Pohanka, E., Margreiter, R. \& Huber, C. (1986) Relationship of interferon-gamma and neopterin levels during stimulation with alloantigens in vivo and in vitro. Transplantation $41,716-719$.

19. Rubin, L. A., Kurman, C. C., Fritz, M. E., Biddison, W. E., Boutin, B., Yarchoan, R. \& Nelson, D. L. (1985) Soluble interleukin 2 receptors are released from activated human lymphoid cells in vitro. J. Immunol. 135, 3172-3177.

20. Tomkinson, B., Brown, M. C., Ip, S. H., Carrabis, S. \& Sullivan, J. L. (1989) Soluble CD8 during T-cell activation. J. Immunol. 142, 2230-2236.

21. Nishanian, P., Hofmann, B., Wang, Y., Jackson, A. L., Detels, R. \& Fahey, J. L. (1991) Serum soluble CD8 molecule is a marker of CD8 T-cell activation in HIV-1 disease. AIDS 5, 805-812.

22. Fahey, J. L., Taylor, J. M. G., Detels, R., Hofmann, B., Melmed, R., Nishanian, P. \& Giorgi, J. V. (1990) The prognostic value of cellular and serologic markers in infection with human immunodeficiency virus type 1. New Engl. J. Med. 322, 166-172.

23. Romeo, F., Pellicia, F., Cianfrocca, C., Gallo, P., Barilla, F., Cristofan, R. \& Reale, A. (1989) Determinants of endstage idiopathic dilated cardiomyopathy: A multivariate analysis of 104 patients. Clin. Cardiol. 12, 387-392.

Univ.-Doz. Dr. D. Fuchs

Institut für Medizinische Chemie und Biochemie Universität Innsbruck

Fritz-Pregl-Straße 3

A-6020 Innsbruck

Austria 